\title{
5 \\ Individual Motivation, \\ Collective Responsibility: \\ Reinforcing Bonds of Community
}

In their literature about the counts of Anjou and Blois the monks of Marmoutier exhibited a growing interest in treating the group or community in tandem with the individual and in complementing discussions of exterior reputation with discussions of the inner person and his or her motivation. These wedded themes of community and self recur as well in Marmoutier's twelfth-century literature for and about the monks and their community.

Personal motivation and fraternal connection were important themes in the intellectual awakening of the twelfth century, and they were central to the spirituality of the newer religious orders. But in assessing the literature from Marmoutier we should not assume that the black monks merely responded to ideas and concerns that originated elsewhere. A rhetorical concern with the internal experiences of the individual may have been introduced to the Benedictines from outside their own order. Nevertheless, like other people in the twelfth century, they perceived that their community was becoming increasingly complex. Their appeals to internal experience represent their own attempts to meet the challenges of a society that created new kinds of social experience and threatened to undermine the traditional bonds of the Benedictine community. To understand the problem as the monks of Marmoutier perceived it in the twelfth century, we must first examine the traditional Benedictine ideals of community; then we must look at the monastic function of intercessory prayer and its impact on Benedictine ideals and realities.

Thoughts and Deeds

Although the founder of Benedictine monasticism, Benedict of Nursia (ca. 480 to ca. 550), directed his attention to the inner faith of 
the individual monk, the primary focus of his Rule was the relationship between the individual and his community. The central themes of the Rule were humility and obedience-on the one hand, a personal attitude of both body and heart, and on the other hand, a relationship to authority. Within the monastery, as Benedict portrayed it, the watchful eyes of the abbot and the community-the "workshop of virtue"-gently yet sternly compensated for the human frailty of the individual monk, providing him with external sources of conscience, will, and judgment. ${ }^{1}$ Physical presence, external observability, and the way the monks moved together through a daily and yearly cycle of prayers and activities were essential to Benedict's communal system, and indeed these seem at times to overshadow his attention to the inner self. A monk's attitude might remain hidden, but his posture and actions could serve as indications of whether he was attempting to attain sufficient humility. By molding the external behavior of a monk, the community and its abbot might leave an imprint on his conscience. Because actions reflected attitudes, even physical accidents-such as breaking a dish while washing it or stumbling over a word while praying-were punishable errors. Punishment usually involved a public ritual by which the offender was brought before the community's gaze and its collective judgment. Even an excommunicated monk, who had been excluded from the oratory and the common table, could not escape this collective gaze. "Visibly present in his absence," the excluded monk still lived within the abbey's walls and daily called attention to his shameful status by prostrating himself before the other monks as they left the oratory. 2

Tenth-century sources suggest that in the early stages of Cluniac reform the black monks continued to adhere to Benedict's depiction of the relations between individual and community, thoughts and deeds. John of Salerno's Life of Abbot Odo of Cluny (927-42) provides ample evidence for an emphasis on deeds, for literal adherence to various external actions prescribed by the Rule, and for the central role the abbot played in the spiritual development of individual monks. Similarly, in a sermon for the feast of Saint Martin, Odo himself (who had been a canon at Saint-Martin of Tours) articulated his version of a Benedictine emphasis on external deeds: "Therefore while we have the time let us do good works and let us not add sin to

I. RB 1980: The Rule of Saint Benedict. On humility of body and heart, 7:62, pp. 4849; on purity of heart, 20:3, pp. 64-65; on obedience, exterior source of judgment and will, chap. 5, pp. 34-37.

2. $R B$ 1980, chaps. 44-46, pp. 92-95. The quotation is from Fulton, "Liminal Status of the Excommunicated Monk." 
sin. . . . For if perverse thoughts depart from God, how much more do perverse deeds depart from him? If on the Day of Judgment we are going to give an account for our idle words, what will it be for perverse works?" 3 In addition to stressing the importance of correct action, Odo of Cluny, like Benedict before him, was mindful of the internal experience of the monk. He hoped his own spiritual writings could move other monks to be vigilant- "lest we harden our hearts" - and to reflect upon the fate of their own souls. 4

Despite the similarities between Odo of Cluny's monastic ideals and those of the Benedictine Rule, however, monastic life and practice in the tenth century differed in at least one fundamental way from what had been described in the Rule: the daily life of monks had come to focus on providing vicarious intercessions for the souls of the dead. While knights fought and peasants labored in the fields, Benedictine monks prayed for the souls of benefactors, of kin, and most especially, for the souls of their fellow monks-not only those of their own abbey, but also those of abbeys to which their houses were joined in confraternity. 5

This intercessory function, which first became important in the

3. "Ergo dum tempus habemus operemur bonum, nec adjiciamus peccatum super peccatum. . . . Perversae namque cogitationes separant a Deo, quanto magis perversa opera? Si de verbis otiosis redituri sumus rationem in die judicii, quid erit de perversis operibus?" (Odo of Cluny, "Sermo in festo Sancti Martini," PL 1 33:750); John of Salerno, "Vita Sancti Odonis," PL 133:43-86, trans. Sitwell, I-88; Rosenwein, Rhinoceros Bound: Cluny in the Tenth Century, 84-100.

4. "Charissimi Patres et fratres; in quantum justi, Patres, in quantum peccatores, socii et fratres, admonendo et obsecrando dico, ne obduremus corda nostra" (Odo of Cluny, "Sermo in festo Sancti Martini," PL I 33:750).

5 . Monks in western Europe began offering intercessory prayers even before the time of the Carolingians. Nevertheless, Benedict of Aniane was a central figure in passing that function on to ninth- and tenth-century monasticism. See, on Benedict of Aniane, Semmler and Bacht, "Benedikt von Aniane," and Semmler, "Benedictus II." Drawing on Semmler's work, Barbara Rosenwein has depicted a fundamental distinction between the monastic ideals of the Carolingian Benedict of Aniane and the ideals of the tenth-century Cluniacs. Benedict of Aniane included liturgical offices that were not in the Benedictine rule, but his central goal was to pare down the liturgical practices of the monasteries of his day. By contrast, the spirit of Cluny in the tenth century was one of eclecticism and liturgical expansion. Benedict of Aniane had cut the number of psalms recited each day to under 75; the Cluniacs in the tenth century expanded the number to at least 138: see Rosenwein, "Rules and the 'Rule' at Tenth-Century Cluny"; Rosenwein, Rhinoceros Bound, 84-100. Other discussions of the Carolingian roots of Cluniac liturgy include Bishop, Liturgica Historica, 214-21; Schmitz, "Liturgie de Cluny"; Schmitz, "Influence de Saint Benôit d'Aniane"; Molinier, Obituaires français au Moyen Age, 2I ff.; Bredero, "Cluny et le monachisme carolingien."

For a discussion of the distinctively central role that intercession for the dead played at Cluny, see Le Goff, Birth of Purgatory, 124-27, and Neiske, "Vision und Totengedenken," 164-79, I 84; Heath, Crux Imperatorum Philosophia: Imperial Horizons of the Cluniac Confraternitas; Wollasch, "Überlief erung cluniacensischen Totengedächtnisses"; Huyghebaert, Documents nécrologiques. 
seventh and eighth centuries, was largely responsible, in the tenth and eleventh, for the enormous success of the black monks. Laypeople seeking relief for their sins showered abbeys like Marmoutier with landed gifts, and as a result the monastic liturgy expanded to the point that it virtually filled the entire day. At Cluny, during the abbacy of Saint Hugh (1049-I I09), the monks prayed each year for ten thousand individually remembered souls, and at all such abbeys the prayers escalated to the point that the monks' life became an almost constant round of ritualized liturgical offices. 6

The enormous growth of the liturgy of the black monks, and of the landed gifts that nobles bestowed upon them so they would pray for their souls, began to peak in the second half of the eleventh century. ${ }^{7}$ About the same time, certain religious reformers represented as a problem the institutional expansion of the black monks, including the intercessory function that stood behind it. Ritualized deeds, they maintained, threatened to overwhelm the inner life of monks. Saint Anselm observed of Cluny that monks there were so busy performing the liturgy that they had no time to study; Peter Damian noted that they had barely a half-hour to themselves each day. ${ }^{8}$ Along similar lines, the Carthusians, whose order had its beginnings in 1084, and the Cistercians, whose order arose in 1098, proclaimed their return to the original purity of the Benedictine Rule, with its much more restricted horarium; their detachment from entanglements with the secular realm, including incomes associated with intercessory prayer; and their devotion to apostolic poverty, which meant-in intentional contradistinction to the "poverty" of the black monks-simplicity in architecture, in clothing, and in liturgical decoration. Although the Cistercians did not directly attack the black monks' intercessory function or totally eliminate offices for the dead, many of their criticisms of liturgical extravagance and worldly

6. In the mid-tenth century the monks at Cluny chanted I 24 psalms each day. By the second half of the eleventh century they were reciting 250 each day: see Peter the Venerable, Statuta, p. 66 n, citing Schmitz, "Liturgie de Cluny," 89, and John of Salerno, "Vita Sancti Odonis," I, PL I 33:43-86, trans. Sitwell, p. 33 and n. I). See also Hunt, Cluny under Saint Hugh, 99-123, and McLaughlin, "Consorting with Saints." On the remembrance of ten thousand souls at Cluny, see Heath, Crux Imperatorum, 80; Wollasch, "Cluniacensisches Totenbuch aus der Zeit Abt Hugos von Cluny." For further discussion of Cluniac liturgy and remembrance, see Hallinger, Gorze-Kluny, I:26 ff.; Bishop, Liturgica Historica, 228-29.

7. Noreen Hunt treats Abbot Hugh's tenure (I049-II09) as a major turning point in the abbey's size and empire and sees Hugh himself as the last of the abbots to retain an earlier spirit of simplicity: see Cluny under Saint Hugh. Marmoutier's turning point in terms of the number of priories and possessions came under Abbot Albert (1032-64): see Gantier, "Recherches sur les possessions et les prieurés de l'abbaye de Marmoutier," 53(1963): 100.

8. Eadmer, Life of Saint Anselm, p. 9; Peter Damian, Epistolae, 6:5, PL 144:380. 
entanglements arose because they envisioned the monastic life more as a quest for personal salvation than as one of corporate intercession. 9 They even curtailed the burden of intercessory responsibilities by avoiding the practice of individual remembrances. The Carthusians went still further in their disengagement. They recorded the names of no donors in their martyrologies, performed no anniversary masses, and did not encourage visitors. 10 In conjunction with their avoidance of liturgical accretions and obligations toward the outside world, the new orders placed considerable importance on the individual reflection and personal devotion of each monk. Cistercians especially produced numerous lyrical and insightful accounts of interior spiritual experiences and mystical devotion.

Despite the criticisms of zealous reformers and the personal conversions of individual monks such as Adam of Perseigne, who left Marmoutier sometime after I 80 to become a Cistercian, black monks continued to provide a vital service in the twelfth century, and they were hardly prepared, nor would they have found it possible, to unburden themselves of their lands, their architectural monuments, and their intercessory obligations. ${ }^{11}$ Still, there were in their midst voices of reform and renewal: Peter the Venerable, abbot of Cluny

9. John Van Engen makes the point about the Cistercian emphasis on personal salvation rather than liturgical intervention: see "'Crisis of Cenobitism' Reconsidered," 296-97, and his Rupert of Deutz, 314-22. Bernard of Clairvaux and Hugh of Pontigny criticized Marmoutier's proprietorship of parish churches: see Bernard of Clairvaux, Letter 397, PL I 82:606-9.

10. On Cistercian prayers for the dead, see Laurent, "Prière pour les défunts et les obituaires dans l'ordre de Cîteaux." On the Cistercian reform, see Lackner, Eleventh-Century Background of Cîteaux, 217-73; Bishop, Liturgica Historica, 228-29. On Cistercians and Carthusians, see Little, Religious Poverty and the Profit Economy, 84-87, 90-96. On the Carthusians, see anonymous monk of La Grande-Chartreuse, "Doctrine monastique des coutumes de Guigues." For contemporary observations and criticisms (implicit and explicit) of the shortened Cistercian liturgy, see Peter Abelard, Epistolae, io (to Bernard of Clairvaux), PL 178:339; Wilmart, "Riposte de l'ancien monachisme au manif este de Saint Bernard," 334-35; Talbot, "Date and Author of the Riposte," 72-80; Van Engen, Rupert of Deutz, 300-306; Hunt, Cluny under Saint Hugh, 48; Folz, "Pierre le Vénérable et la liturgie," I 52. On the liturgies of the Carthusians and Cistercians, see King, Liturgies of the Religious Orders, I-I 57 .

I I. Jean Bouvet, who edited Adam of Perseigne's letters, was not absolutely certain that Adam resided at Marmoutier, but he was unaware of Guibert of Gembloux's statement that a defense of the epithet "par apostolis," which was applied to Saint Martin, had been written "ab armario Majoris Monasterii, domno Adam." It was Adam (later of Perseigne) who provided that discussion in his letter 10 . Bouvet was also misled by his assumption that Guibert did not visit Marmoutier until I I94, when Adam was already abbot of Perseigne. Guibert's visit, however, took place in 1180-81: see "De cultu Sancti Martini apud Turonenses extremo saeculo XII," 244; Adam of Perseigne, Lettres, ed. Bouvet, 7-29, I63 n. I, I64-79; Delehaye, "Guibert, Abbé de Florennes et de Gembloux." Gerald of Alne, another Cistercian abbot, may also have begun his monastic career at Marmoutier: see Martène, Histoire de l'abbaye de Marmoutier, 2:87. 
between I I 22 and I I 56, and Rupert, abbot of Deutz between I I 20 and I I 29, advocated a renewed fervor and commitment in fulfilling the task of monastic prayer and intercession. Black monks graciously welcomed those who aspired to the more personal and ascetic accomplishments of the eremitical life: Abbot Hugh of Cluny encouraged the hermit Anastasius to come to Cluny so he would serve as an example to its monks; and Peter the Venerable created a space within the monastery, forbidden to all outsiders, where the monks could "assiduously burn in God's presence with the holy and secret perfume of prayers . . . as if they were in the desert."12

Peter the Venerable also felt compelled to cope with the length of the liturgical offices at Cluny by cutting out pauses between psalms. Like his predecessor Abbot Hugh, he set aside special days for the commemoration of the dead, possibly, as Noreen Hunt suggested, in an attempt to ameliorate the burden of individual remembrances by consolidating them on special days. ${ }^{13}$ Peter's attempts to reform the liturgy at Cluny may have been motivated in part by his desire to respond to the criticisms of the new religious orders and by his perception that the monks at Cluny should be allowed the opportunity to develop a more inward, meditative religious life. 14 But Peter's statutes also indicate that the length of the liturgy at Cluny was a real problem. Most of the monks' commemorative and intercessory responsibilities were performed on behalf of fellow monks of the abbey. 15 Thus that Cluny had grown from one-hundred monks in the mideleventh century to four-hundred in Peter's day suggests that liturgical burdens increased about fourfold. 16 Peter the Venerable noted that the material aspects of commemoration-distribution of food to the poor on behalf of monks who had recently died-could impoverish the abbey, and he claimed, when he cut out the pauses between psalms,

12. "Ubi sancta et secreta orationum aromata deo assidue accenderent . . velut in heremo" (Peter the Venerable, Statuta, 53, p. 83); Constable, "Monastic Policy of Peter the Venerable," 126-38; Van Engen, Rupert of Deutz, 300-306; Hunt, Cluny under Saint Hugh, 48; Folz, "Pierre le Vénérable et la liturgie," i 50-6I.

I 3. Hugh set aside January $3 \mathrm{I}$ for the commemoration of dead monks and the Monday af ter Trinity Sunday for those buried in the cemetery. Peter the Venerable added the vigil of Saint Michael's Day for the commemoration of Cluny's monks and the vigil of the Conversion of Saint Paul for the commemoration of the parents of monks: see Hunt, Cluny under Saint Hugh, 104; Ulrich of Cluny, Antiquiores consuetudines, I:26, PL 149:673; Peter the Venerable, Statuta, 8, pp. 47-48.

14. Orderic Vitalis accused Peter of "rivaling the Cistercians and other seekers after novelties" (Historia ecclesiastica, 13:13, ed. Chibnall, 6:426-27).

I 5. This is evident in Cluniac necrologies, which listed many more names of monks than of familiares: see Wollasch, Synopse der cluniacensischen Necrologien, vol. 2.

I6. On the size of Cluny, see Hunt, Cluny under Saint Hugh, 82-89. 
that "neither the hours of the day nor those of the night would be able to suffice" if the monks were to allow time for the desired pauses. 17 Although statistics are not available for the number of monks at Marmoutier, we know that its success paralleled that of Cluny and that the mother house must have been large in the twelfth century, since it provided the personnel for the abbey's extensive priories and deaneries, which numbered (on the Continent alone) I I 4 by I I 00 and I 5 I by the early thirteenth century. ${ }^{18}$ Liturgical adjustments also suggest that Marmoutier, like Cluny, was feeling the pressure of internal growth. The author of Marmoutier's customal, writing sometime after I I24, stated that it had once been the custom at his abbey to recite Psalms 5 and 14 for each dead brother for a total of thirty days, "but because of the great multitude of the dead, for whom it was most difficult to observe a trental, it was decided that these psalms would be said at all times and at all hours without intermission." The psalms were now recited every day, not for specific dead brothers, but for whomever had recently died. 19

17. "Quia ad istud nec diurnae horae, nec nocturnae, visae sunt posse sufficere" (Peter the Venerable, Statuta, I, pp. 4I-42). On distributions of food, see statute 32, pp. 66-67, and Peter's "Dispositio rei familiaris Cluniacensis," cited by Constable in the note to that statute. For general discussion of Peter's reforming decrees, see Knowles, "Reforming Decrees of Peter the Venerable"; Constable, "Monastic Policy of Peter the Venerable," I 2930; Folz, "Pierre le Vénérable et la liturgie," I49-50; Van Dijk, "Historical Liturgy and Liturgical Studies," I 74-77.

Already about ro83, Ulrich of Cluny observed that there was virtually never a time when the monks of Cluny did not have to perform commemorative offices for those who had recently died: see Ulrich of Cluny, Antiquiores consuetudines, I:3, 7, PL 149:647, 652 (on Ulrich's date, see Hunt, Cluny under Saint Hugh, I2).

I8. There are no sources for the size of Marmoutier, but the assertion by the author of the Return from Burgundy that Marmoutier had 140 monks plus one abbot at the time of the Viking invasions could well have been a projection into the past of his own experience at the abbey. Since most abbeys were growing in the first half of the twelf th century and monks were aware of this, the author may have projected into the past a number that was somewhat smaller than the size of the abbey at the time he wrote: see De reversione beati Martini, 2I. It was Ursmer Berlière who surmised that the number of monks at Marmoutier must have been quite large in the twelf th century to provide the personnel for the priories and deaneries ("Nombre des moines dans les anciens monastères," 246-47). On the number of Marmoutier's priories, see Gantier, "Recherches sur les possessions et les prieurés," 55(I965):7I-79.

19. "Consuetudinis enim erat antiquitas ut haec duo, idest Verba mea minus, et psalmus Voce mea pro unoquoque fratre nostro triginta diebus dicebantur, sed pro nimia multitudine morientium, quorum trigenaria observare difficillimum erat, difinitum est ut omni tempore per omnes horas absque intermissione dicantur" (Antiquae consuetudines Majoris monasterii, chap. 48, fol. I I I). The Verba mea was said every day after matins, the Voce mea during the familiar psalms. According to this customal (which was written af ter I I24), sometime after I 104 a vespers for the dead was set aside on the feast of the Purification of the Virgin, on behalf of the parents of all the monks. The passage concerning the vespers for parents of monks mentions the parents of Abbot William, who became abbot in I IO4 (ibid., chap. 45, fols. $108 v-109)$. 
There were tensions, then, between the black monks' desire to partake of the new, more meditative spirituality and their continued liturgical obligations. Nevertheless, like the members of the newer orders, the black monks began to express themselves with the language of inner experience. The spiritual readings and devotional writings of the older Benedictines began to assimilate and resemble those of the Cistercians. Twelfth-century libraries of older Benedictine houses, including Marmoutier, possessed copies of Cistercian sermons. 20 Peter the Venerable's collection of miracle stories-the De miraculis-anticipated those of Cistercians such as Caesarius of Heisterbach. Both Peter and Caesarius recounted ghost stories, propagandized the Christian sacraments, and attempted to communicate the needs and implications of an inner spirituality that emphasized sincere contrition and the fate of souls that had been saved but still needed to be purged of their sins. 21

At Marmoutier, too, the monks attempted to open up new spaces for interior fervor and personal expression. Toward the beginning of the twelfth century, several monks of Marmoutier retired to the nearby island of Saint-Nicholas (on the Loire), where they apparently built a wooden chapel and began to live an eremitical life. In I 23 they gained permission to build a stone hermitage, which continued to provide a place of meditation for Marmoutier's monks until about I I 30, when the site became a religious refuge for women.22 Several of Marmoutier's monks retired to the abbey's priories to live ere-

20. Chibnall, World of Orderic Vitalis, 91-92; Tours, Bibliothèque Municipale, MS. 344 . This manuscript, which includes sermons of Bernard of Clairvaux, has the following note at fol. I93v: "Liber iste est Sancti Martyni Majoris monasterii . . . factus est tempore Guillelmi, armarii, anno octavo Hervei abbatis [1187]" (Catalogue général des . . . bibliothèques publiques de France, 37:1:265-66). Other twelfth-century manuscripts that were in Marmoutier's library in the eighteenth century contain works by Isaac of Stella, Bernard, and other Cistercians, but I have no direct evidence that these manuscripts were at Marmoutier in the twelfth century: see Tours, Bibliothèque Municipale, MSS. 137, 246; Catalogue général, 37:1:87-90, 175-77.

2I. Peter the Venerable, De miraculis; Caesarius of Heisterbach, Dialogus miraculorum; Schmitt, "Revenants dans la société féodale"; Le Goff, Birth of Purgatory, 177-81, 300-3 10; Ward, Miracles and the Medieval Mind, 192-200; Patin and Le Goff, "A propos de la typologie des miracles dans le Liber de miraculis de Pierre le Vénérable," I 8I-89; Constable, Cluniac Studies, introduction, iii-iv. The ghost stories of Peter the Venerable and Caesarius drew on a long tradition stretching back to the early Christian period, which had been considerably expanded in the eighth and ninth centuries. Earlier Cluniac ghost stories had also focused on the special relationship between the returning souls of the dead and their requests for spiritual assistance: see Neiske, "Vision und Totengedenken," I37-85. In their collections of miracles and ghost stories, however, Peter the Venerable and Caesarius of Heisterbach emphasized contrition and confession in ways that the earlier works had not.

22. Oury, "Erémitisme à Marmoutier," 322-24. 
mitical-or simply quieter-lives. ${ }^{23}$ In I 87 Abbot Hervé of Villepreux retired to the grotto of the seven sleepers, a cave above the abbey's main church, where he continued to lead an eremitical life for another sixteen years. ${ }^{24}$ Finally, a work titled Deeds of the Abbey of Marmoutier in the Eleventh Century presented the monks with examples of those who, while remaining among the other brothers, quietly exceeded the devotional requirements of the abbey's customs. John, who was ten years old, never laughed as children do, and he outdid the other boys in the abbey by rising for vigils even though the younger members of the abbey were allowed to sleep at that hour; a sacristan secretly served the others at night, drawing water and filling the lavatories; a monk wore out his knees with genuflections during his frequent private devotions. 25

In the language of their sermons the monks of Marmoutier paid close attention to the issues of intention and sincerity. An anonymous author of a collection of sermons from the second half of the twelfth century emphasized, in a way that Sulpicius Severus had not, Saint Martin's role as a preacher. "With words, examples, and miracles," the saint "provoked and converted thousands of men"; his teaching "illuminated" unbelievers "with the light of truth." 26 Some of the language in these passages was inspired by Carolingian spiritual writings, yet it is significant that the twelfth-century monk chose to portray his patron saint as a master of speech at a time when rhetoric,

23. Abbot Baudry of Saint-Nicholas returned to his mother house of Marmoutier before I033, then went on to the priory of Tavant to lead an eremitical life: see Charter of Fulk of Anjou, PL I 55:482; Guillot, Comte d'Anjou, 2:C77. Odo Rigaldus's episcopal visitations to some of Marmoutier's priories in the thirteenth century suggest that they still provided a place of quiet retirement for sick and elderly monks: see Odo Rigaldus, Register of Eudes of Rouen, 96.

24. Chronicon abbatum Majoris monasterii, 324; Oury, "Erémitisme à Marmoutier," 321 22. Hervé may have written a collection of sermons (Bibliothèque Nationale, MS. lat. 3823): see Leclercq, "Recherches sur d'anciens sermons monastiques," 8-10. Arnold of Bonneval, friend and biographer of Bernard of Clairvaux, and indeed one of the great spiritual thinkers of his age, began his monastic career at Marmoutier. On the one hand, this suggests that Marmoutier may have provided him (and possibly Adam of Perseigne as well) with a relatively good education. On the other hand, Arnold's career suggests there was probably more room for inner development at a Benedictine house of smaller proportions than Marmoutier: see Canivez, "Arnaud de Bonneval”; Prévost, "Arnaud, Arnold, et Ernaud de Bonneval."

25. De rebus gestis in Majori monasterio, 398, 402-3, 404-5. On the dates and manuscripts of this work, see Source Appendix, I-D.

26. "Verbis pariter exemplis atque miraculis multa hominum milia provocavit atque convertit," "Homines autem luce veritatis . . . illuminabat" ("In translatione beati Martini, sermo secundus," Bibliothèque Nationale, MS. lat. I24I 2, fol. IO5v, col. I; ibid., "Sermo primus," fol. I05, col. I). 
popular preaching, and the possibility of changing the hearts of men and women were becoming major concerns in Scholastic circles. 27

The author of Marmoutier's sermons stressed Saint Martin's preaching, but he also recognized, as had ancient and early Christian theorists of rhetoric, the difficulty of bringing about a motivational change with words alone. 28 Thus he attributed the success of Martin's preaching not only to his words but also to his example and miracles, which reinforced the sincerity and truth of his spoken message. 29 This author understood that while words can convey the content of deep spiritual truths, they can also serve as masks, disguising the real self. Receptivity to the Christian message cannot be demonstrated with words alone, since it frequently occurs, as the Lord himself declared, that "the people honor me with their lips but their heart is far from me [Is. 29:I3, Matt. I 5:8, Mk. 7:6]." 30 A confession of faith, the author of the sermons insisted, must be accompanied by deeds, which are signs of an inner piety, one which arises from the "root of faith" or "from the heart." 31

Even works, which are more trustworthy than words alone in serving as outward signs of sincerity, are not infallible signifiers of the inner self, and they do not suffice for a true piety. In the end, the author of these sermons suggested-and here we encounter the chasm separating his own spirituality from that of Odo of Cluny-only God can perform the final test of sincerity, because a piety of deeds must always be accompanied by the proper attitude. The monks of Marmoutier can imitate the virtue of their patron Saint Martin, but they must couple an imitation of his voluntary poverty with faith-the confidence that they are saved by God's grace. They must strive to ensure that their meekness, a visible mien they assume in their relations with other men, is accompanied by true humility, which is visible only to God. 32 On one level the author of these sermons was consistent with the dual themes-interior and exterior-of the Rule of Saint Benedict. But

27. Alcuin, "De vita S. Martini" and "Sermo de transitu S. Martini," PL Ior:657-64. For further discussion of the background to this theme, see my dissertation, "Societal Change and Religious Expression: Saint Martin's Cult at Tours," $278 \mathrm{ff}$.

28. Romilly, Magic and Rhetoric in Ancient Greece; Murphy, Rhetoric in the Middle Ages, 286-94; Farmer, "Softening the Hearts of Men: Women, Embodiment, and Persuasion in the Thirteenth Century."

29. "In translatione beati Martini, Sermo secundus," Bibliothèque Nationale, MS. lat. I 24I2, fol. Iosv, col. I.

30. Ibid. fol. IO5, col. 2. The second legend about Count Odo and Countess Ermengard described Odo in a similar manner: see above, chapter 4.

3 I. "Corde," "ex fidei radice" (ibid., fol. Ios, col. 2).

32. "De transitu beati Martini, Sermo quartus," ibid., fol. I s6, col. 2; "De transitu beati Martini, Sermo quintus," ibid., fol. I07v. col. I. 
whereas Benedict had emphasized that monks must answer outwardly to their abbot and community, this author emphasized instead that each must answer to God, who alone knows the true inner self.

\section{Individual and Community}

In the Benedictine Rule and the writings by and about Odo of Cluny, the idea that outward deeds reflected the true inner character of the monk was closely related to the ideal that the community could serve as the outward conscience of the individual. Abbots were to keep careful watch over their charges, measuring inward spiritual progress by observing outward bearing. The difference between the earlier writings and the later ones from Marmoutier thus points not only to a new emphasis on inner spiritual experience, but also to a perception that relationships between persons in positions of authority and those who answered to them, or indeed between the individual and the community, were problematic. No monk or abbot, the author of Marmoutier's sermons implied, can truly know the soul of his neighbor.

This new assessment of the problem of knowing the heart of another is representative of changed perceptions that resulted at least in part from the language of interiority that the Cistercians and others like them were promulgating. More important, however, this new attention to the possibility of a disjunction between deeds and character reflects the fact that the monastic community of the twelfth century was a different physical and psychological entity than the one Benedict and Odo of Cluny had envisioned and experienced. It could no longer be assumed that the members of a monastic community would share the same physical space, the same rhythm of liturgical activities.

It was the escalating growth of these monastic houses, especially the more successful ones such as Cluny and Marmoutier, that transformed the nature of the community. As their liturgical and administrative responsibilities expanded, the monks needed to distribute their human resources across large distances and to divide up their liturgical and organizational labor. Members of the mother house could be sent out to distant priories or deaneries, and they might not see their brothers for months or years. Even those who remained at home were expected to fulfill some of their collective responsibilities in places or at times when no one else was around. The watchful gaze of the community became less and less evident in the daily lives of the monks. 
We might expect that the intensification and expansion of the monks' liturgical obligations would have enhanced the effectiveness of the authority that both the community and the abbot were supposed to hold over the wills of the monks. The monitoring of every action of the individual was, after all, an inherent aspect of collective liturgical activity, and participation in an elaborate ritual life served to merge the identity of the individual with that of the community as a whole. But the actual results of liturgical expansion were quite different. Since the eighth century, monasteries had been fulfilling their intercessory functions not only by expanding the conventual liturgy but also by encouraging, or requiring, monks who were priests to perform private, intercessory masses. The proliferation of side altars in monastic churches (we know of at least three in Marmoutier's Romanesque church, but there were certainly more) and the increase in the number of monks who were priests indicates that within monasteries private masses were steadily gaining importance from the eighth century on. By the tenth century about 55 percent of monks were priests. By the time of Peter the Venerable, the percentage at Cluny must have been much higher, since he complained that at times the celebration of private masses threatened to reduce attendance at the abbey's conventual offices to one-quarter of the abbey's monks. 33 Statistics are not available for the number of priest-monks at Marmoutier, but the author of the Deeds of the Abbey of Marmoutier proclaimed that the "numerous priests" of the abbey offered the mass continuously from "dawn until the dinner hour." 34

Private masses represent, at least on one level, a division of labor in the liturgical sphere. At Cluny, whenever a monk died, six of the

33. Peter the Venerable, Statuta, 6, pp. 46-47; see also statute 72 on p. I02; Hunt, Cluny under Saint Hugh, I08-9; Folz, "Pierre le Vénérable et la liturgie," I 56-57. On the percentage of monks who were priests in the earlier period, and on the role that private masses played in monasteries, see Vogel, "Vie quotidienne du moine en Occident à l'époque de la floraison des messes privées." On side altars, see Conant, Benedictine Contributions to Church Architecture, 20-21. We know very little about the plan of the Romanesque church of Marmoutier that was dedicated in 1096 and probably completed after that date. Between I 218 and about I350 a Gothic structure was built over the Romanesque one, which was eventually demolished. In I 818-19 the Gothic structure was demolished: see Lelong, "Recherches sur l'abbatiale de Marmoutier à l'époque romane," and his "Observations et hypothèses sur l'église abbatiale gothique de Marmoutier." Although the physical evidence is lacking, the written sources show that at least three eleventh-century abbots of Marmoutier were buried next to different side altars: see Chronicon abbatum Majoris monasterii, 318-19.

34. "Mos erat ipsius cenobii ut a prima aurora usque in horam prandii propter sacerdotum copiam continua missarum celebratio protraheretur" (De rebus gestis in Majori monasterio, with corrections from Charleville II7, which are printed in Van der Straeten, "Recueil de miracles de S. Martin dans le manuscrit II 7 de Charleville," 90). 
abbey's priests were to take turns performing masses until the dead monk had received the thirty masses that were owed to him. At Marmoutier all priests were obliged to perform private masses for a deceased monk until his body was buried; after the burial, priestmonks chose to perform private masses for the dead monk in order to pay off personal obligations. ${ }^{35}$

Even as private masses gained importance, the conventual horarium continued to grow, and as it did, further division of labor became necessary. More and more monks were granted exemptions from participating in the common liturgy. These included not only priests who performed private masses (although Peter the Venerable attempted to draw them back to the common liturgy by insisting that they could not perform private masses during the conventual mass), but also monks who were responsible for the smooth functioning of the abbey-cooks, refectorians, even scribes working on important manuscripts. 36

Another change that led to the transformation of the religious community was the monks' residing, sometimes alone and of ten in groups of less than six, away from their abbeys in the granges and smaller priories that served as administrative and spiritual centers on parcels of dispersed landed property. Marmoutier's numerous priories were situated all over western and northern France and even in England (see map s). This system of priories and granges had already begun to take shape at Marmoutier and Cluny in the tenth century, but it did not lead to an administrative restructuring until the middle of the eleventh century. ${ }^{37}$ In the twelfth century, when the number

35. According to Ulrich, all the priests sang mass on the day a brother was buried, but af ter the burial six priests shared the remaining responsibilities: see Ulrich of Cluny, Antiquiores consuetudines, 3:29, PL 149:775. The parallel distinction at Marmoutier was that bef ore the burial all priests performed private masses "pro gratia" rather than "pro debito" (presumably this second expression meant "for personal debts"). After a monk had been buried, whoever said masses for the dead monk paid off such personal debts: "Quamdiu corpus super terram fuerit, omnes sacerdotes missas privatas pro eo singulariter debant cantare. Nulla tamen illarum missarum pro debito repulsabitur, sed pro gratia. Tumulato autem corpore, quisquis pro eo cantaverit a debito solvi incipiet" (Antiquae consuetudines Majoris monasterii, fol. I Iov).

36. Hunt, Cluny under Saint Hugh, 108-9; Antiquae consuetudines Majoris monasterii, fol. I 6 (scribes exempt from certain liturgical offices). See also Leclercq, Aux sources de la spiritualité occidentale, I1 4-20.

37. On Marmoutier's priories, see Gantier, "Recherches sur les possessions et les prieurés de l'abbaye de Marmoutier." Gantier observed that the prioral organization did not emerge until the second quarter of the eleventh century and that the word for "prior" did not appear in the charters before about 1075. On the priories in England, see Martène, Histoire de l'abbaye de Marmoutier, I:393.

Hunt (Cluny under Saint Hugh, 55-56) argued that deans were a new development in the mid-eleventh century and that the major concern in the customals of that time was to 
Black dots $=$ priories of Marmoutier. There were over 150 by the early thirteenth century.

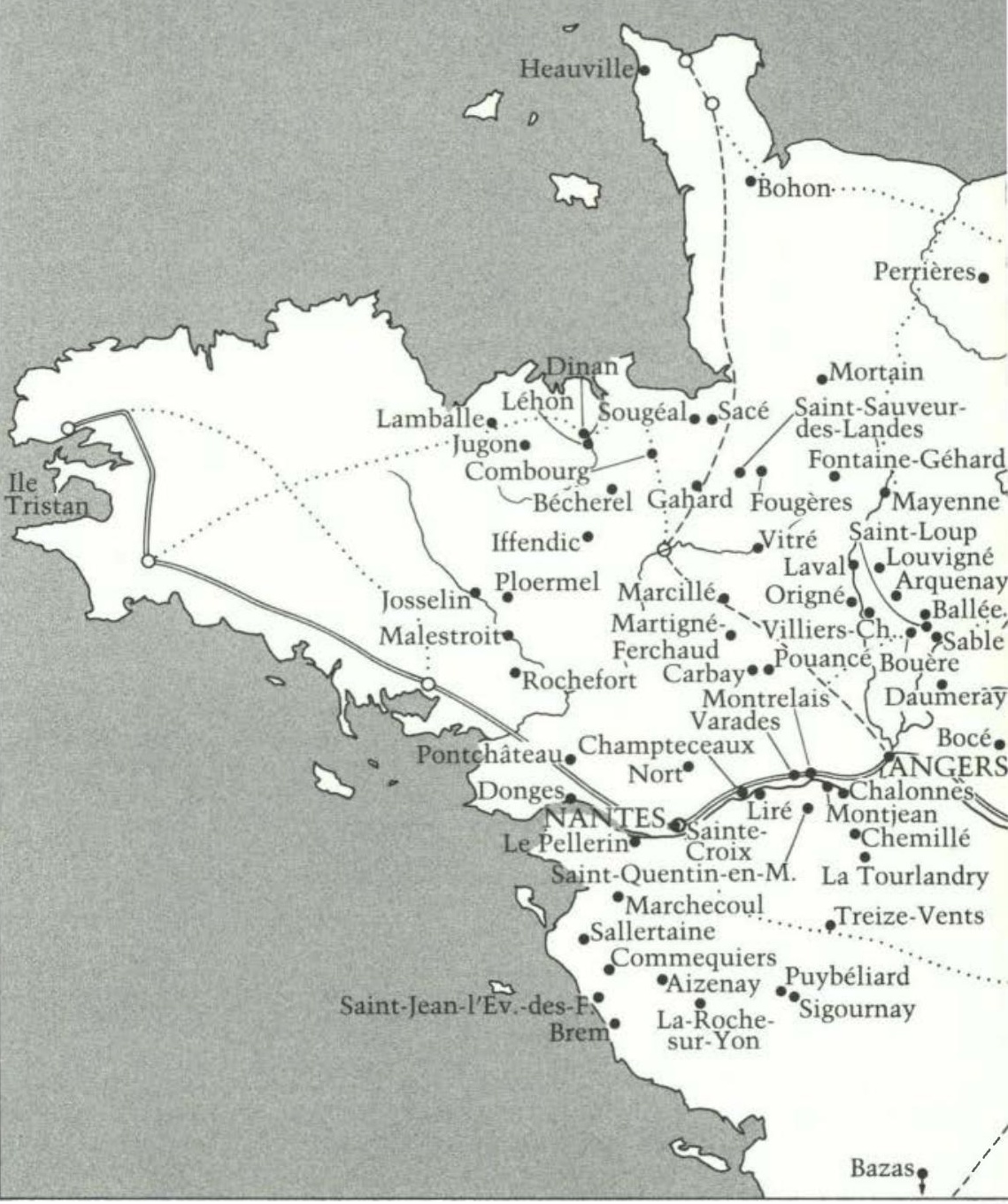

MAP S Priories of Marmoutier about I200. Adapted from Ganticr, "Recherches sur les... prieurés." 


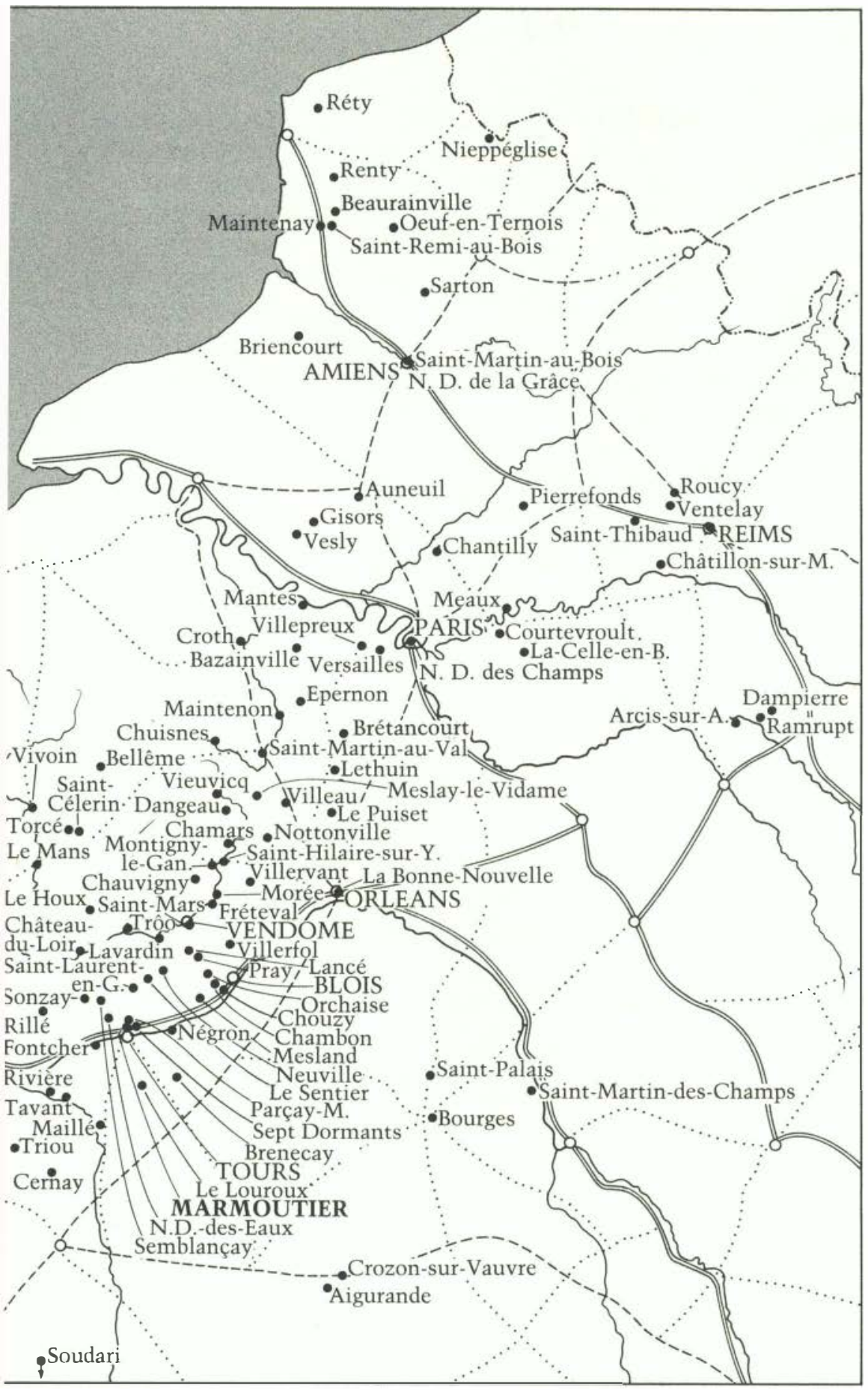


and size of donations declined, administrative responsibilities probably continued to grow. Endowed anniversary masses, which became especially popular toward the end of the twelfth century, required new kinds of record keeping. Dispersed modest gifts complicated the problems of administration, and they frequently needed defending in court. 38

There was a significant difference of scale between the "empires" of Cluny and Marmoutier in the tenth century and those of the twelfth. The monks of the later period were confronted with a much more extensive problem of holding the system together and instilling a sense of community in those monks who resided at the outlying posts, of ten far from the mother house. It was difficult for the community to serve as a "school of virtue," a source of judgment, will, and conscience for the monks who were scattered about in the tinier of Marmoutier's and Cluny's enclaves. The pious Abbot Baudry may have wished to pursue an eremitical vocation when he retired, sometime before I033, to Marmoutier's priory at Tavant, but the twelfthcentury author of the Deeds of the Abbey of Marmoutier was more concerned that men would behave like Ulrich, the irresponsible steward of the same priory. ${ }^{39}$ Similarly, the statutes for the priories and granges of Marmoutier, which may have been written in the twelfth century, indicate that Marmoutier's leaders were anxious to ensure that the priors and monks of the subject houses and granges would continue to fulfill their liturgical duties and that they would retain their distance-in behavior, dress, and eating habits-from the secular countryside that seemed to encroach upon them. The author of the statutes encouraged the monks in the priories to avoid being alone,

regulate this unusual situation for monks-to ensure that monastic discipline would be maintained as fully as possible. Jacques Dubois concurred that the remarkable expansion of dispersed centers of administration (deaneries and priories) took place in the eleventh and twelfth centuries, but he also reported that Cluny had thirty-two deaneries at the end of the tenth century ("Vie des moines dans les prieurés du Moyen Age"). For a good discussion of the bureaucratization of a monastery, which resulted from the growth in the number of priories, see Johnson, Prayer, Patronage and Power: The Abbey of la Trinité, Vendôme, $52 \mathrm{ff}$. She wrote that at La Trinite the number of monks holding office rose from 29 percent in the eleventh century to $6 \mathrm{I}$ percent in the twelfth and that the reason for this increase was the proliferation of priories.

38. McLaughlin, "Consorting with Saints," chap. 7; Marot and Lemaître, Répertoire des documents nécrologiques français, I:19-2I; Constable, Monastic Tithes, 144 (on Marmoutier defending its tithes in courts); White, Custom, Kinship, and Gifts, 83 (on Marmoutier's monks spending time in court); Southern, Westem Society and the Church, 232-36.

39. Charter of Fulk of Anjou, PL is5:482 (see Guillot, Comte d'Anjou, 2: $\mathrm{C}_{3} 6, \mathrm{C}_{77}$, on the date and authenticity of this charter); De rebus gestis in Majori monasterio, 400 . During the abbacy of Barthelemy of Marmoutier (1063-84) there were eighteen monks at Tavant: see Martène, Histoire de l'abbaye de Marmoutier, 1:429, and Bibliothèque Nationale, MS. lat. I2878, fol. 299 (copy from Marmoutier's Touraine cartulary). 
because they could provoke each other "by word and example" to keep regular observances, and their company could thus provide an important antidote to the temptations of secular life. 40 Saint Benedict was apparently correct in assuming that human flesh is weak and that individuals are more likely to adhere to an ascetic way of life when they have someone nearby-not just the Divine Father-to whom they must answer for their behavior.

Just as the distance separating monks from each other expanded, so did the distance between the abbot and his charges. At home in the mother house, the abbots of Benedictine monasteries the size of Marmoutier and Cluny were consumed with administrative duties. It is thus unlikely that they continued to live up to the image of the discerning shepherd that the Benedictine Rule had portrayed and Odo of Cluny had attempted to emulate. Benedict's abbot was a wise teacher, a stern taskmaster, and a tender father who responded appropriately to the variety of temperaments among his monks, assisting each to achieve the level of personal piety he was capable of while at the same time providing him with an external source of conscience and authority. ${ }^{41}$ How, though, could the abbot of a prestigious and prosperous twelfth-century house, such as Marmoutier or Cluny, carry out such intimate scrutiny and judgment? He had hundreds of monks under his immediate care and many more to account for in the deaneries and dependent priories. To keep tabs on the priories, Abbot Albert (1037-64) established a yearly chapter general of the priors of Marmoutier's dependent houses and cells (and in doing so, he anticipated the abbot of Cluny by at least sixty-eight years). But despite the annual meetings, Marmoutier's abbots needed to make frequent visits to the priories. 42

Guests, too, intruded upon Benedictine houses, making demands

40. "Immo cum sociis sint frequenter, et vos provocent ad regulares observantias pro modulo suo, verbo pariter et exemplo, servantes cum eis honestatem et communem vitam in victu et vestitu" ("Statuts des prieurés de Marmoutier," p. II, chap. 12, with emendations from Tours, Bibliothèque Municipale, MS. 94, fol. 39v; see also pp. 7, 8, 10). For my argument that the Tours manuscript of the statutes may represent a version from the twelfth century, see Source Appendix, I-G. In three of his statutes Peter the Venerable attempted to deal with the abuses and potential abuses in the priories. His primary strategy was to attempt to ensure that in as many cases as possible individual priories would have at least twelve monks: see Peter the Venerable, Statuta, 4I, 42, 46, pp. 75, 78.

One example of how the countryside infringed on Marmoutier's priories is the way benefactors frequently reserved rights of procuration at the priories and employed them as virtual hunting lodges: see Gantier, "Recherches sur les possessions et les prieurés de l'abbaye de Marmoutier," 54(1964): 17, I 34-35.

4I. $R B$ 1980, chaps. 2, 5, pp. 18-27, 34-37.

42. Chronicon abbatum Majoris monasterii, 318; Martène, Histoire de l'abbaye de Marmoutier, I:348; Gantier, "Recherches sur les possessions et les prieurés," 54(I964): 64; Hunt, Cluny under Saint Hugh, I74; Johnson, Prayer, Patronage and Power, SI. 
on their abbots' time. The Benedictine Rule had indicated that abbots were supposed to eat with their guests separately from the other monks, but in an apparent effort to prevent the abbot's loss of contact with his flock both Marmoutier and Cluny decided that he should always eat in the main refectory with the other monks. ${ }^{43}$ By breaking with one specific command of the Rule these abbeys were attempting to salvage its essence, which rested so firmly on the bond between abbot and community. Their efforts, however, point to the strains of success. Because of their stellar reputations, both Marmoutier and Cluny had a steady stream of important ecclesiastical and secular visitors, among them popes and kings. Their abbots may have continued to eat with the monks, but they could not ignore the presence of such eminent visitors. In the course of the twelfth century, moreover, the abbots of Marmoutier and Cluny built separate sleeping quarters for themselves and showed an ever-growing propensity for ceremonialism and display. As a result, the gap between them and their monks widened.44

Finally, because abbeys like Marmoutier and Cluny had international reputations, their abbots played key roles in ecclesiastical and political affairs, which pulled them away from their internal responsibilities. Similarly, because the affairs of a monastery were now tied to larger ecclesiastical politics, its abbot had to spend time in Rome and at church councils defending his house and its rights. Marmoutier's own struggle for exemption, for instance, compelled various abbots to make trips to Rome and to church councils. 45

The Deeds of the Abbey of Marmoutier, written between I 37 and the

43. Hunt, Cluny under Saint Hugh, 49-5o; Peter the Venerable, Letters of Peter the Venerable, 28, vol. I, p. 74; Guibert, Abbot of Gembloux, "Epistola," 609. See also Peter the Venerable, Statuta, 23, p. 60, for evidence of frequent visitors at Cluny.

44. Abbot Hugh of Cluny slept in the common dormitory, but a separate abbot's house was built in the twelfth century. Hugh maintained simplicity, but later abbots cultivated display. At Marmoutier, Abbot Robert of Blois (1 165-76) built a separate chapel and sleeping quarters for the abbot, and the burial of Abbot Hugh of Rochecorbon (1210-27) was carried out "more solemnly" than that of any previous abbot: see Hunt, Cluny under Saint Hugh, 49 ff.; Chronicon abbatum Majoris monasterii, 321, 326. Penelope Johnson also traces an evolution at $\mathrm{La}$ Trinité of Vendôme during the eleventh and twelfth centuries from the image of the abbot as father to that of the abbot as lord (Prayer, Patronage and Power, 50SI).

45. Hunt, Cluny under Saint Hugh, 52. Marmoutier's abbots attended the following church councils: Clermont in ro95, Poitiers in Iro5, Loudun in I109, Reims in II 30 , and Tours in I162. Moreover, in I 196 Abbot Geoffrey was one of the major guarantors in the peace settlement between Richard the Lion-Hearted and Philip Augustus: see Martène, Histoire de l'abbaye de Marmoutier, I:521, 2:10, I5, 79, I25, I74; Charter of Alexander III of I 162, in Papsturkunden in Frankreich, n.s. 5, no. II7, pp. 206-9. In II 84 Abbot Herveus of Marmoutier was delegated by the pope to adjudicate in the dispute between the canons of Saint-Martin and the burghers of Châteauneuf: see chapter 9 at note 8. 
end of the twelfth century, shows that at least one monk from that abbey attempted to address the attenuation of fraternal bonds that resulted from the growth of Marmoutier's empire and the division of labor within its walls. Like the collection of sermons, the Deeds of the Abbey of Marmoutier suggests that the abbey's monks were attuned to the new inward piety of the twelfth century. But this text also represents an attempt to create an adhesive that would bind together the dispersed community, whose existence could no longer rest on coincidence of time, place, and collective activity. That adhesive was the internal motivation of every monk.

In many ways the Deeds of the Abbey of Marmoutier closely resembles Peter the Venerable's De miraculis, and in both collections we can detect a preoccupation with contrition, purgatory, and the fate of the individual soul. 46 But whereas Peter the Venerable's stories served a variety of rhetorical purposes for a variety of audiences-nobles who might contemplate seizing monastic property, heretics, monks of Cluny-the author of Marmoutier directed his message almost exclusively to his fellow monks there. And whereas Peter the Venerable wanted to demonstrate the efficacy of the sacraments in general, the author of Marmoutier focused, in his prologue and in ten of his fifteen stories, on monastic assistance for the dead and dying. 47 For Marmoutier's author, assistance to the dead and dying was at the heart of his abbey's spirituality and was central to its sense of community as well.

In its focus on the salvation of the soul and its message that Marmoutier and its patron saint could expedite that salvation, the Deeds of the Abbey of Marmoutier was a traditional text. Since the tenth century the monks of both Marmoutier and Cluny had attempted to turn the minds of men and women to the fate of their souls and to convince them that favorable relationships with the monks and their saint would provide the best assurance for a comfortable afterlife. Like earlier works from Cluny, the Deeds of the Abbey of Marmoutier depicted the visitations of dead men who wanted, and indeed received, vicarious assistance from the monks of those two houses. 48

In the earlier works, however, the horror of the Day of Judgment

46. De rebus gestis in Majori monasterio; Peter the Venerable, De miraculis, PL I89:85I954.

47. De rebus gestis in Majori monasterio, paragraphs I-6, 8-I I, I6, Pp. 395-40I, 404. The printed edition has sixteen stories (paragraphs 2-17), but paragraph is is not in the twelf thcentury manuscript, Charleville II 7 , so I have not included it in the total.

48. For examples from Marmoutier in the tenth century, see introduction to part 2 at notes Io and I I. On Cluny, see above at note 5 and Heath, Crux Imperatorum Philosophia, 98 $\mathrm{ff}$. On ghost stories from Cluny, see Neiske, "Vision und Totengedenken," I64 ff. 
loomed much larger than it did in the twelfth century. There is no discussion at all, in the Deeds of the Abbey of Marmoutier, of the possibility of damnation. Purgation, in this world or in the next, is the only punishment at issue. Demons are so powerless, or perhaps we should say men are so powerful, that a mere declaration by a dying monk that he places his faith in the cross can cause the devil and his entourage to "vanish like smoke." 49 Even Saint Martin's power recedes as the personal faith of the individual becomes more efficacious. In their tenth-century charters the monks of Marmoutier had described the passive hope that its benefactors could place in Saint Martin, who had the ability to "snatch" their souls "from the infernal flames." 50 Martin, in tenth-century depictions, was a symbol of charity and mercy. Nevertheless, the word "mercy" attained much more prominence in twelfth-century writings, where it was directly associated with the individual believer's decisive acts of faith and contrition. Hence, though Martin remained, in the Deeds of the Abbey of Marmoutier, a symbol of God's mercy and a special tutor and assistant of Marmoutier's monks, the believing monk himself (like Count Odo, in the third legend about him) now effected his own soul's salvation. This new focus on the will-not only of the individual who sought salvation but also of the community of other individuals who assisted him - set the Deeds of the Abbey of Marmoutier apart from tenth- and early eleventh-century monastic literature.

In its opening frame the Deeds of the Abbey of Marmoutier briefly addresses Marmoutier's reputation, which rests on the abbey's efficacy in assisting the souls of sinners who are "not yet worthy to possess the joys of the heavenly kingdom." 51 That reputation places Marmoutier on a par with other great monasteries of the age. Indeed, in an effort to enhance Marmoutier's comparative status, the author opens his own collection of stories with two he has borrowed from other authors: from Guibert's Life of Pope Leo IX, an anecdote about a

49. De rebus gestis in Majori monasterio, 6, p. 397.

so. See introduction to part 2 at note I I. See also Odo of Cluny, "Sermo de combustione basilicae beati Martini," PL I 33:748; "Hymnus de Sancti Martini archiepiscopi," PL I33:SI 5; "Hymnus in Honorem S. Martini," PL I33:516. In these works Odo developed the idea that Martin's cape (which he originally shared with a poor man in an act of charity) could clothe his devotees on the Day of Judgment, providing them with "a garment of justice" so that their "shamefulness" would not "be revealed bef ore the highest judge." For the evidence that the "Sermo de combustione" was written by Odo, see Source Appendix, II-A.

SI. "Animas caelestis regni gaudia nondum meritas possidere" (De rebus gestis in Majori monasterio, in Charleville I 17 , fol. I08). The phrase is in a passage borrowed from Guibert, $V$ ita Leonis IX papae, in Acta sanctorum, April, 2:662. 
troop of ghosts who made a penitential pilgrimage from Marmoutier to the abbey of Farfa, near Rome; and from Ralph Glaber, a story about an African anchorite who declared to a traveler from Marseilles that one abbey in the entire Roman world exceeded all the others in liberating souls: "For the frequent offering of the vivifying sacrifice thrives so greatly there that hardly a day goes by in which such commerce does not snatch souls from the power of the evil demons." Ralph had written these words about Cluny; the author of Marmoutier found it convenient to apply them instead to his own abbey. 52

In his commentary on these two stories, the author linked Marmoutier's efficacy to one of its traditional sources of legitimacy-the patronage of Saint Martin, who "by means of the merits of his humility" was able to obtain absolution for sinners who turned to the abbey of Marmoutier for assistance. But the author also gave credit to the "zeal" of the brothers, who performed private masses almost continuously. 53 Thus the abbey's external reputation depended in part on the will of each monk to maintain it.

Having dealt briefly with Marmoutier's intercessory service for the world at large, the author turned to the subject of most of his stories-the monks' task of assisting each other in their quest for a peaceful hereafter. The author's underlying message was that the monks actualized their community by fulfilling, through vicarious acts of penance, the biblical injunction to "bear one another's burdens" (Gal. 6:2). They could fulfill this command only if each of them was endowed with sufficient motivation and compassion. Deeds alone were not enough-they needed to be grounded in the proper attitude.

52. "Tanta enim viget in eo vivifici sacrificii frequens immolatio ut nulla pene dies pertranseat in qua non de potestate malignorum demonum tale commercium animas eripiat" (De rebus gestis in Majori monasterio, in Charleville 117 , fol. 107, and Bibliothèque Nationale, MS. lat. I 3899); Ralph Glaber, Historiarum libri quinque, s: I, p. 125. Even in one of the manuscripts of Glaber's History someone scratched out the word for Cluny and replaced it with "Majoris monasterii": see Ralph Glaber, Historiarum libri, p. I25, note, citing Bibliothèque Nationale, MS. lat. 6I90. On Guibert's Life of Leo IX see the preceding note.

53. "Quidni enim illic votorum obtineatur effectus, ubi patrocinatur prepotens et sublimis ille sacerdos Martinus, qui humillimi magistri Iesu Christi humilis et constans imitator, maxime humilitatis meritis . . . inibi fideliter oratum venientibus obtinere potest a peccatis absolutionem? Nec incongrue etiam revelante Deo predictus heremita de studio et efficacia fratrum eiusdem monasterii circa cultum et frequentationem sacramentorum, que supra retulimus, vel vidit vel effudit . . . mos erat ipsius cenobii ut a prima aurora usque in horam prandii propter sacerdotum copiam continua missarum celebratio protraheretur" (De rebus gestis in Majori monasterio, p. 395, with corrections from Charleville I I7, which are printed in Van der Straeten, "Recueil de miracles de S. Martin dans le manuscrit I 17 de Charleville," 90). 
According to the author, the monks who resided at Marmoutier in the eleventh century had possessed this attitude, and his own contemporaries at the abbey would do well to imitate their "wondrous ardor of love":

Neither do we think that we should leave out the praiseworthy and imitable custom they observed on behalf of their dead brothers. Whenever one of them had recently died, his confessor was questioned in public regarding the penance imposed on him. And when it was heard, you would have seen the burden of the dead brother eagerly taken up with wondrous compassion by the brothers. This one seized for himself [the recitation of] psalms, this one masses, another fasts, and another disciplining with whips. Truly with a wondrous ardor of love that apostolic saying was fulfilled, "bear one another's burdens and thus you will fulfill the law of Christ." And when the dead brother had been exonerated from the imposed satisfaction he passed on, as we believe, to the place of rest and the convent procured more abundant grace. 54

The author of the Deeds of the Abbey of Marmoutier reinforced his message concerning internal motivation and spiritual interdependence with stories about miraculous visions in which the monks maintained intimate contact with those in the hereafter: with Saint Martin, the personal protector of contrite monks and the corporate patron of the abbey as a whole; with angels, who came to carry away the souls of dying monks; and with dead monks who were undergoing purgatorial punishment for their sins. 55

The efficacy of the vicarious spiritual assistance that the monks provided depended on the faith and sincerity of the one receiving it. Each had to recognize for himself the mercy of God, and each had to feel truly sorrowful for his sins. These attitudes were requisites for salvation. Indeed, as the story about a monk who disavowed the religious life at Marmoutier makes clear, they were the only requisites, even for the most depraved of sinners.

54. "Unde nec laudabilem et imitandam eorum circa fratres defunctos antiquitus observatam consuetudinem pretereundam censemus. Cum enim aliquis fratrum nuper obisset, confessor eius in communi super indicta ei penitentia inquirebatur. Qua audita, mira compassione videres certatim a fratribus defuncti fratris onus suscipi: hic psalmos, ille missas, alius ieiunia aliusque disciplinas verberum sibi rapiebat. Implebatur prof ecto miro caritatis ardore apostolicum illud: 'Alter alterius onera portate, et sic adimplebitis legem Christi'" (De rebus gestis in Majori monasterio, no. I, p. 395, following variations in Charleville II 7 , which are printed in Van der Straeten, "Recueil de miracles . . . de Charleville," 90).

55. On the genre of monastic ghost stories, see Le Goff, Birth of Purgatory, 177-81, 300310; Schmitt, "Revenants dans la société féodale"; and Neiske, "Vision und Totengedenken." 
The former monk, who served as a secular priest after he left Marmoutier, had become well "versed" in the ways of the world. 56 He accumulated much wealth, and he lived with a concubine who bore him several children. His soul might have been lost, except that God's kindness "wondrously . . . and mercifully" awoke him from his stupor. 57 The concubine and children died, the renegade monk fell ill, and at last, "with great contrition of the heart" he "returned to himself."58 Thinking at first that it was too late to make amends, the sinner cried abundant tears, but then he gained confidence, exclaiming to himself, "I believe and I have faith that He who mercifully supported the thief who confessed to him on the cross will not reject me, who am also truly penitent." $59 \mathrm{He}$ then called the monks of Marmoutier to his side, asked to be flogged with whips as an appropriate form of satisfaction for his sins, and requested that they dress him, for a second time, in the monastic habit.

After these things had been done according to his wishes, the sick man had a vision in which the devil proclaimed to Saint Martin and Saint Benedict that they had unjustly accepted into their midst a man whose "tears of only one hour" followed upon a long life of sin. 60 But Martin replied with the favorite phrase of twelfth-century theologians that "in whatever hour the sinner sighs, all his iniquities will be handed over to oblivion." 61 The saint then absolved the man, exhorting him to sin no more. He told him that he would recover from his illness and return to Marmoutier, where he should carry out whatever discipline of satisfaction his master should impose on him, because his death was not far off. The sinner did as he was told, and though he saw the devil once again, lurking near his deathbed, he died with a joyful face, confidently proclaiming, "I have protectors against you-Martin, the Miracle Worker [signipotens], and Father Bene-

56. "Mundana non mediocriter callebat prudentia" (De rebus gestis in Majori monasterio, no. II, p. 400).

57. "Cum benignitas divina mirabiliter eum simul et misericorditer visitavit" (De rebus gestis in Majori monasterio, no. II, p. 400, with corrections from Charleville I 17, fols. I 17I I 7 v).

58. "Tunc demum in se reversus . . cum magna cordis contritione excogitare cepit" (De rebus gestis in Majori monasterio, no. I I, p. 400, with corrections from Charleville I 7 , fol. I I 7v).

59. "Credo enim et confido, qui et latronem in cruce se confitentem misericorditer suscepit, me quoque veraciter poenitentiam non abjiciet" (De rebus gestis in Majori monasterio, no. I I, p. 40I, with corrections from Charleville I I 7, fol. I I 7v).

60. "Unius horae lacrymas" (De rebus gestis in Majori monasterio, no. II, p. 401).

61. "In quacumque hora peccator ingemuerit, omnes iniquitates ejus oblivioni tradentur" (De rebus gestis in Majori monasterio, no. II, p. 40I, with corrections from Charleville II 7 , fol. I I $8 v$ ). 
dict. . . . 'I do not fear what man will do to me' [Heb. I 3:I6]."62

In a number of ways this story resembles the third legend about Count Odo of Blois. Both stories distinguish the worldly reputation and outer appearance of these sinners from their sinful state: Odo was one of those insincere believers "who confess to know God, but who nevertheless deny God with their actions"; the renegade monk "carried himself guiltily before God . . . but honestly before men."63 Both stories portray a fight between Saint Martin and the devil over the soul of the sinner, and both refer to the doctrine of true inner contrition by citing the twelfth-century phrase about the efficacy of the sinner's sigh.64 In both stories the emphasis is on God's mercy and Martin, the patron of Marmoutier, serves as its agent. Finally, both stories indicate that though contrition qualifies one for God's mercy and removes the threat of damnation, the sinner is still required to make amends, either by undergoing the discipline of satisfaction in this life or by suffering purgatorial punishment in the next.

Despite the similarities between the two stories, however, one salient aspect of the anecdote about the renegade monk distinguishes it from the legend about Count Odo and highlights the central characteristics of the Deeds of the Abbey of Marmoutier: Odo's legend dealt with spiritual interdependence among laypeople as well as between laypeople and monks; the story about the renegade monk, by contrast, like another seven of the fifteen stories in the same collection, dealt exclusively with interdependence among monks. 65 The central message of the Deeds of the Abbey of Marmoutier was that Marmoutier could provide-as long as the monks continued to will it-a desirable and safe environment for the dying and the dead. Those in the secular realm could best reap the benefits of the abbey by undergoing conversion and joining its ranks. Even a last-minute conversion was better than none. Indeed, the story about the renegade monk was not the only one concerning the custom of joining the abbey ad succurren-

62. "Protectores habeo contra te. Adest Martinus signipotens, adest et pater Benedictus, non timeo quid faciat mihi homo" (De rebus gestis in Majori monasterio, no. I I, p. 40I). The epithet "signipotens" was apparently applied exclusively to Saint Martin: see Du Cange, Glossarium, 7:483.

63. "Confitentur se nosse Deum, factis autem negant" (Liber de restructione Majoris monasterii, 356); "etsi coram Deo culpabiliter . . coram hominibus tamen honeste se agebat" (De rebus gestis in Majori monasterio, no. I I, p. 400, with corrections from Charleville I17, fol. I17). Like the author of the anonymous sermons from Marmoutier, the author of the De rebus emphasized that only God can know the true inner man: see above at notes $35-37$.

64. See chapter 4 at note 33 .

65. De rebus gestis in Majori monasterio, nos. 2-5, 9, 10, 16, pp. 395-97, 399-400, 404. Only the prologue and no. 12 mention spiritual relations with outsiders. 
dum in order to die as a monk. The author also described a layman and two other priests who donned the religious habit as their final hour approached.66 Within the haven of the abbey, the author indicated, "Father" Benedict and Martin-the abbey's "guardian" and "provider"-offered special protection. 67 Clothed in Marmoutier's habit, flagrant sinners could make appropriate satisfaction for their sins, and as the ghost of a dead monk made clear, it was better to make such satisfaction on this side of the grave than on the next, since even the greatest mortal punishment would seem light compared with the purgatorial fires. 68 Finally, and most important of all, Marmoutier's monks provided each other with assurance, vicarious strength, and spiritual assistance during illnesses, at the moment of death, and as long as help was still needed after death. The man who joined the abbey ad succurrendum gained spiritual power by dying in that holy place, surrounded by the other monks (see plate 4). At the critical moment when the soul left the body, the prayers of the other monks would "confirm" the strength of the convert's own faith and even chase away demons. And after the convert's death his brothers would do for him what they would do for any member of the abbey-they would complete whatever satisfaction he still owed for his sins. 69

The purpose of the Deeds of the Abbey of Marmoutier was to arouse a sense of obligation in the monks, so that they would continue to provide this assistance to the dead and dying. The author told ghost stories to heighten the monks' awareness of their interdependence, and he appealed to the emotions to strengthen the complex network of relationships that constituted the community. He attested, moreover, that the bonds of community did not end at death's door.

The first emotion the author appealed to was fear-fear that those who did not live up to their responsibility to others would know not

66. De rebus gestis in Majori monasterio, nos. 5, 6, 8, pp. 396-99.

67. "Pater," "tutor," "provisor" (De rebus gestis in Majori monasterio, nos. Io and 6, pp. 401 and 397). Despite the emphasis on Martin's role in delivering and guarding God's mercy, the author of the De rebus gives him epithets that underscore his power and formal role ("signipotens," "tutor") rather than the name father, which is applied to him in the anonymous sermons (see below, chap. 6 at notes $45 \mathrm{ff}$.). One possible explanation for this attention to Martin's power is that the De rebus was a work of propaganda meant to kindle the zeal of the monks, and an emphasis on Martin's fatherhood would have enhanced the monks' confidence rather than admonishing them to do better. Also, even when he is delivering mercy Martin must protect his tutees from the devil, and his power is thus required.

68. De rebus gestis in Majori monasterio, no. 8, p. 399.

69. "Quantum prosit fides propria, probat aliena" (De rebus gestis in Majori monasterio, no. 3, p. 396, with corrections from Charleville I I7, fol. I09v). 


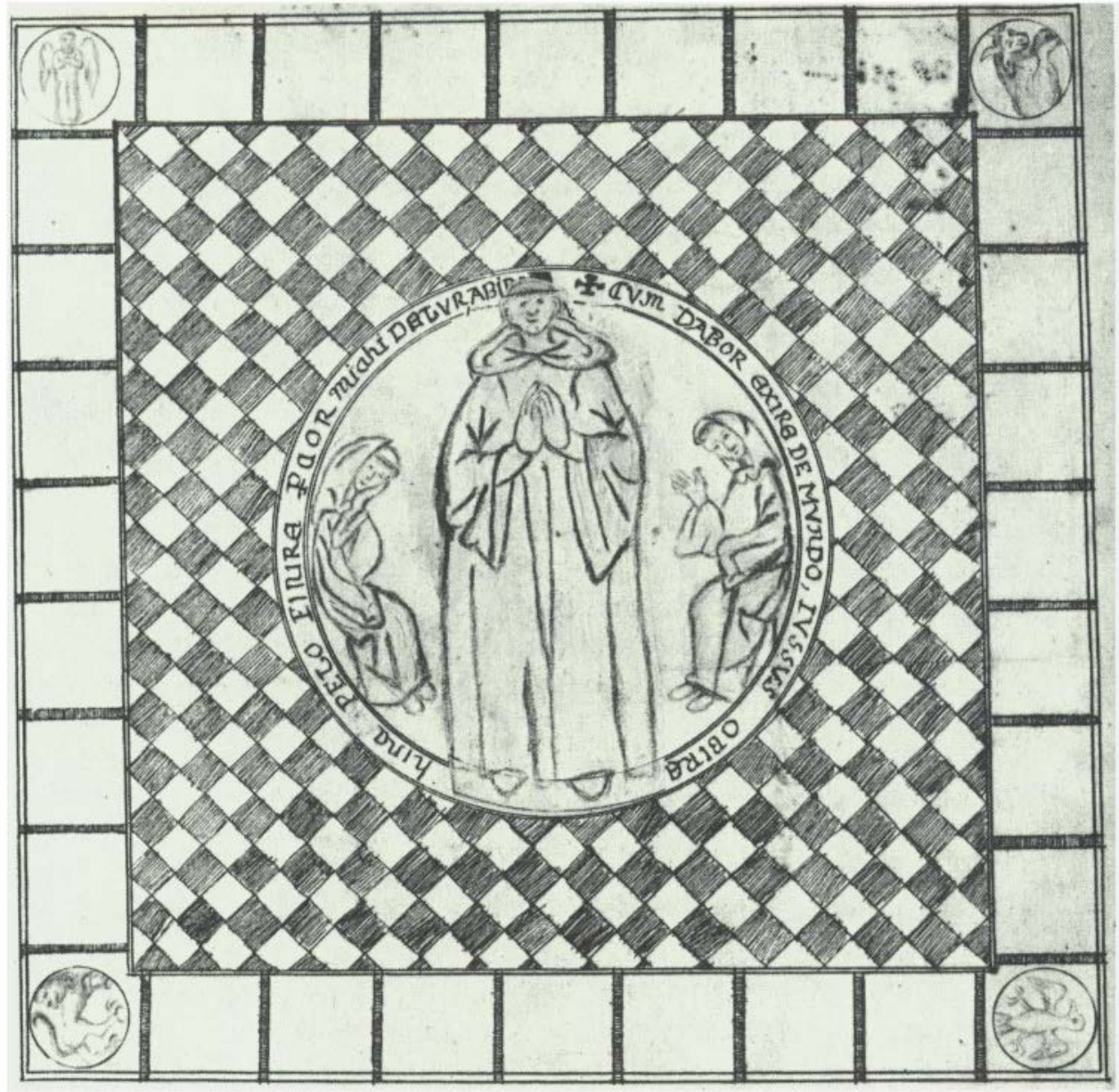

Plate 4. Floor of the chapel of Saint Benedict. The decorated floor of Marmoutier's infirmary chapel (dedicated in 1162 and destroyed in 1699; see Lelong, "Etudes sur l'abbaye de Marmoutier," 290, 301) gave visual expression to assistance for the dead and dying, which held a central place in the spirituality of Marmoutier. The life-sized image of a dying monk was flanked by one monk making a gesture of mourning and a second praying for him. In accordance with Saint Martin's assertion that "it is not decent for a Christian to die in any way except lying on ashes" (Sulpicius Severus, Epistolae, 3: 14), monks were apparently placed on this inage, which had been covered with ashes from Ash Wednesday. The inscription read (here I follow 1)om Martène's notes [Histoire, 2:124] rather than the slightly different inscription depicted by Housseau): "Cum dabor exire de mundo, jussus obire, Hic peto finire, precor hinc mihi detur abire" ("When, bidden to die, I am given to exit from this world, I desire to meet my end here, I pray that I may be able to leave from here").

The style of the floor was Gothic, perhaps of the thirteenth century. On the custom of dying on ashes, see Gougaud, Anciennes coutumes claustrales, 8I. I thank Walter Caen of Yale University for this advice concerning the date of the floor. Bibliothèque Nationale, Collection Housseau, MS. S, fol. 139. Photograph courtesy Bibliothèque Nationale. 
only God's mercy but also his judgment. That judgment would be meted out to individuals, not-as in many tenth- and early eleventhcentury monastic stories - to the community as a whole. 70 All the monks owed service to each other and to the dead, but each was responsible, as an individual, for bearing his share of the burden. And the dead themselves could demand and administer punishment for those who had been judged irresponsible in meeting their collective responsibilities. ${ }^{71}$

Two ghosts who visited Abbot Bartholomew (I063-84), for example, sent a warning to those monks who were not "zealous enough for their dead brothers," that each of them owed a debt to the dead, which he had to pay off while he was alive. If any of them failed to do so, the suffrages performed for him after his death would benefit not him, but the dead to whom he was still indebted. 72 Each monk ran a personal risk of incurring punishment, each accumulated or paid off his own debt to the dead. And each had to consider the possibility that punishment would come not from a distant God, but from a brother who had eaten in the same refectory, slept in the same dormitory, prayed in the same oratory. Indeed, it is significant that the ghosts in the Deeds of the Abbey of Marmoutier tended to visit brothers who knew them and to come alone or in pairs rather than in large groups. ${ }^{73}$

Ulrich, the monk who served as the steward of Tavant, encountered two such brothers. Apparently Ulrich had yielded to the temptations of a life of relative independence while he was living at the priory of Tavant. He thought no one would know, so he cheated his dead brothers of Marmoutier of some of the income that had been designated for the benefit of their souls. Ulrich's living brothers were

70. For an example of collective punishment, see Odo of Cluny, "Sermo de combustione," PL I 33:729-49.

7I. There were some precedents in ninth-and tenth-century ghost stories for the theme of the punishment of those who neglected to live up to their obligations to the dead: see Neiske, "Vision und Totengedenken," I 53, I6 I. I am not aware, however, of any works that focused exclusively on relationships among monks of the same abbey or that showed the same concern for a sense of monastic community.

72. "Qui defunctis dum vivit quod debet non exsolvit, quod ei defuncto ab aliis exsolvetur, non in eius, sed defunctorum proficiet utilitatem" (De rebus gestis in Majori monasterio, no. 2, p. 395, with corrections from Charleville i 17, fol. I09v).

73. De rebus gestis in Majori monasterio: in nos. 2, 4, 9, and to one or two dead monks visit an individual monk in some kind of intimate setting; in no. 8 a secular priest who had become a monk at Marmoutier before he died visited the priest who had succeeded him at his post, again in an intimate setting. In all these cases except no. Io, the author makes it clear that the living men recognized the dead men, and in no. Io recognition seems implicit to the story. In nos. I I and I7 Saint Martin is accompanied by "a troop" of monks, but in these stories the theme is not the encounter between the living and the dead but Martin's and the saints' assistance or glorious presence. 
not aware of what he was doing, but his dead brothers knew, and they demanded their just deserts:

And therefore it happened that two brothers who had been freed from the body appeared to him in a dream and rebuked him with very harsh words for this injury to the dead. But he was hardened and considered what he had seen as nothing, as if it were a dream. Appearing to him once more, they announced that punishment for his contempt was imminent. Nonetheless, he remained uncorrected. Having returned a third time, they gave him so many floggings that he remained in bed for half a year tortured by the most severe pains. In time he recuperated, but just barely, and he was never able to recover his original vigor. ${ }^{74}$

Lest the other monks of Marmoutier should miss the point of Ulrich's story, the author went on to address them directly: "From this you should infer, reader, what those defrauding their obligations [debita] to the dead can expect in the future punishment, if someone who had not yet departed from the temporal life deserved to be flogged in this way."75

The ghostly visitations to Bartholomew and Ulrich served to elicit the monks' sense of obligation to all their brothers. This obligation was more intimate than that owed to outsiders, but perhaps, in an age when Marmoutier and its empire had become so large, it was not intimate enough. In other stories the author appealed to more personal relationships, suggesting that each monk was at the center of his own community, which grew out of his special ties with other individuals. Those ties could be familial, affective, or contractual.

One dead monk appeared to his confessor seeking reassurance that his confession had been effective and that he was indeed freed from the penalty for his sins. The confessor responded that he himself would answer for the dead man on the Day of Judgment, and at that

74. "Contigit igitur ut ei dormienti duo fratres a corpore soluti per somnium apparerent, et pro hac defunctorum iniuria durissimis eum verbis increparent. Induratus ille quasi somnium nichili pendit quod viderat. Cui denuo apparentes illi pro contemptu vindictam sibi imminere denuntiant. At ille nichilominus incorrectus permansit. Tercio reversi tantis eum verberibus affecerunt ut per annum dimidium lectulo decubans gravissimis doloribus torqueretur. Vix tandem convaluit, quamvis pristinam corporis alacritatem nullatenus recuperare potuerit" (De rebus gestis in Majori monasterio, no. I0, p. 400, with corrections from Charleville I I 7, fols. I I6v- I I 7). For similar stories about ghostly punishments, see William of Malmesbury, De gestis regum Anglorum, 3:293, ed. Stubbs, 2:345-46, and Othloh of Saint Emmerman, "Liber visionum," chap. I6, PL I46:371-72.

75. "Hinc conice lector quid in futuro vindicte mortuorum debita def raudantibus immineat si sic flagellari meruit qui nondum temporali decessarat vita" (De rebus gestis in Majori monasterio, p. 400, with corrections from Charleville II 7, fol. II 7). 
point demons who had been demanding the dead monk's punishment disappeared. 76 The ghost of a usurious priest who had joined Marmoutier ad succurrendum appeared to complain that a mendacious business associate was prolonging his purgatorial punishment. That man, who had borrowed money from the dead usurer, had promised that within a year of the latter's death he would donate to Marmoutier the full amount of the loan. The year came and went, but the promise-sealed with the kiss of peace on a repentant sinner's deathbedhad not been kept: 77 Finally, in a third story, a monk who had been sent to England (apparently to one of Marmoutier's priories there) by Marmoutier's abbot appeared on the day of his death to his brother by birth, also a monk at Marmoutier, asking that "with the intuition of brotherly love" he announce the death to the other monks and request that they perform the office of the dead. 78

In this final story the living monk was stirred by the request of his dead brother, but he hesitated to announce the death, assuming that no one would believe his vision and that the monks in England would eventually send the proper written announcement. Still, the author suggested, God worked to reinforce the proper bureaucratic process. 79 Miraculously, a messenger arrived from England with the written announcement of the death, and the monks all assumed that it was the anniversary of the monk's death. At that point the brother informed the others of the miracle that had just occurred, convincing them that this was the very day of his brother's death.

These stories about broken promises and anxious requests that obligations be met despite the obstacles of time and distance point to the incremental changes that had been transforming the monastic community since the middle of the eleventh century. Like the secular world around it, Marmoutier had changed from an intimate community or set of communities into a complex society, held together not by concrete ties of kinship and dependence, not by exchanges of service, not by physical proximity of time and space, but by abstract concepts, bureaucratic organization, written documents, promises,

76. De rebus gestis in Majori monasterio, no. 4, p. 396.

77. De rebus gestis in Majori monasterio, no. 8, pp. 398-99.

78. "Germanae dilectionis intuitu" (De rebus gestis in Majori monasterio, no. 9, pp. 399400).

79. "Dissimulabat tamen adhuc, reputans quod si vere obisset, fratres cum quibus moratus fuerat eius obitum nuntiare eis non different. Estimabat enim non facile sibi credi potuisse maxime a viris qui somniorum imaginationibus non satis movebant" (De rebus gestis in Majori monasterio, Charleville I 7 , fol. I I6). The printed edition (9, p. 400) says the dead monk's brother did make the announcement, but the officers of the abbey replied: "Non est... consuetudinis nostrae, ut alicui debitum exsolvamus nisi breve allatum fuerit." 
contracts, and money. $80 \mathrm{~A}$ monk continued to belong to Marmoutier not because he lived within its walls and physically engaged with the other monks in its tangible round of prayers and meals, but because his name, inscribed on a piece of parchment in England, could be carried over land and sea to the mother house, which would then fulfill its obligations to his departed soul. A piece of property, such as that at Tavant, belonged to Marmoutier even though the abbot could not physically survey it regularly. Rather, the written record of its administration and the income from its crops could be transported across a considerable distance to the mother house. Money and writing stretch out our relations; they connect us to those who are far afield and make possible bonds and contacts between individuals who are not present to one another and may never meet. ${ }^{81}$ Indeed, it is significant that one of the most salient features of the twelfth-century spiritual revival, the cult of monastic friendship, was characterized by written vows of "intimate" association and commitment and that such vows could be made by men who never met face to face. 82

Money and written records are the prerequisites for bureaucratic organization and abstract community. But in a world in which they

8o. For a similar discussion of the rise of abstract relations in this period, see Marvin Becker, Medieval Italy. On the increased role of written records, see Clanchy, From Memory to Written Record, and Stock, Implications of Literacy, 3-10.

$8 \mathrm{I}$. The role of money and written records in holding together a monastic empire was already evident when Ulrich wrote his customal of Cluny about I083. Although a simple transport of agricultural produce tied the closest priories and deaneries to the mother house, those that were too far away sent money: "His . . . villis quae tam longe sunt positae ut nec vinum nec annona . . possit ad nos pervenire, ibidem venditur, et pretium camerario defertur" (Ulrich of Cluny, Antiquiores consuetudines, 3:I I, PL I 49:75I. A charter from Marmoutier's priory of Laval (ca. I $20 \mathrm{~km}$ from Marmoutier) says that Marmoutier's priories also sent money to the mother house: see Gantier, "Recherches sur les possessions et prieurés de l'abbaye de Marmoutier," s5(1965): 68.

Written records, Breves, that were sent around to the mother house and the priories and deaneries to announce the death of a brother provided the mechanism that held the monastic system together spiritually: see Ulrich of Cluny, Antiquiores consuetudines, 3:30-33, PL I49:775-77; Antiquae consuetudines Majoris monasterii, fol. I09v; Marot and Lemaître, Répertoire des documents nécrologiques, $\mathrm{I}: 20$. On the transformation of Cluny into a money economy in the generation after Ulrich, see Duby, "Budget de l'abbaye de Cluny entre Io8o et I I 5s." See also, on the effects of writing (the loss of the association of words with actuality and presence), Ong, Presence of the Word.

I do not mean to suggest that writing and money had not existed and been used in the earlier period; indeed, written documents-libri memoriales-made possible the numerous bonds that bound Carolingian and Cluniac monasteries to the laity through the obligation of intercessory prayers for the dead. I am suggesting, instead, that as administrative and bureaucratic organization became more sophisticated, written documentation and liquid wealth were used more and became more necessary functionally, not only for the monastery's external relations, but also for its internal life.

82. Morris, Discovery of the Individual; McGuire, Friendship and Community: The Monastic Experience. 
were becoming increasingly necessary, it was of ten difficult to have faith that promises would be kept, obligations honored. The author of the Deeds of the Abbey of Marmoutier apparently sensed this problem of faith and was perplexed by it as well. He suggested that the newer forms of association could be reinforced by older, more concrete, ties such as those of kinship. His description of the appeal to the "brotherly" love between two monks who were also related by blood calls to mind that many new forms of business association-partnerships, companies, banks-were built upon ties of kinship. 83 In a brave new world of long-distance trade, risk, and abstract association, these older, more organic relations might reinforce abstract ties, thereby ensuring that promises would be kept. In the same story about the blood brothers, however, the monastic author also offered some reassurance that the abbey's bureaucratic system would work. The appearance of the divine messenger, who bore the necessary written document, suggested that though Marmoutier's monks might end up dying in England they could be confident that they still belonged to Marmoutier and that God himself was working to hold this detached community together.

The story about the two brothers appealed to and attempted to strengthen a sense of faith-faith that somehow this system, however abstract, however extended, was going to work. In other stories, though, the author's rhetorical aim was not to incite faith but to inculcate guilt, to mold the monks into the kinds of individuals who would themselves uphold this system because they were trustworthy.

Trustworthiness was a central problem in this new world of detached relationships. Why should a man join Marmoutier ad succurrendum, thus entrusting both his property and his soul to the monks, and why should a creditor lend out money if, in this world of greater independence, debtors could escape without making their payments? If abstract relationships were to take hold and flourish, men and women in both the secular and the monastic worlds needed the proper conscience, the sense that even when no one was present the eye of justice and the will of an associate would still prevail.84 Belief in purgatory and stories about returning ghosts could help create a sense that sanctions were at work to enforce this new system of rela-

83. Lopez, Commercial Revolution of the Middle Ages, 74-75; Herlihy, Medieval Households, $89 \mathrm{ff}$.

84. The closest parallel to my discussion here is that of R. Howard Bloch, who argues that in the twelf th century interiority served the purposes of the centralizing monarchy, which needed to create self-governing individuals (Medieval French Literature and Law, 22348). Becker sees an association between interiority and commercial culture, but he does not explain it (Medieval Italy, passim). 
tionships. Those beliefs and stories conveyed the message that partnerships, debts, and promises would be carried over and upheld beyond the threshold of death. The bonds of community, affection, and association between the living and the dead helped strengthen and reinforce the bonds of community, affection, and association among the living.

The ghost stories from Marmoutier indicate that its monks were interested both in inner motivation and in emotional bonds. It would be misleading, however, to assume that these concerns simply paralleled the spirituality of the new religious orders. Marmoutier's monks were searching for, or attempting to mold, more self-conscious individuals, but they were still much more deeply entrenched in feudal society and in the ritual life of the older Benedictines than were the new monks.

Even the language of the ghost stories is more literal and concrete than the lyricism of, say, Cistercian mystical writing. Like the authors of epics, the author of Marmoutier's ghost stories employed few metaphors or figures of speech. $85 \mathrm{His}$ stories could move the monks emotionally, but their persuasive force lay in their concrete realism, not in the emotional or poetic power of their language. A graphic description of the changes in a monk's appearance, for example, communicated the intensity of his struggle with invisible demons: "His eyes swelled with bloody veins and offered, as they twisted around, a horrible appearance. His distorted mouth vomited forth foam colored with blood, while his limbs enjoyed no rest." 86 Passages like this certainly evoke emotional response, but they retain a simplicity and directness in their depiction of inner experience. The author alludes to subjective experience only through external signs. Bitter tears and sighs signify sincere contrition, weeping signifies despair, shaking signifies fear. 87 This is the kind of language that came to predominate in the exempla-edifying tales that communicated the church's moral lessons to the laity. 88 Such language remained much closer to the logic and psychology of oral culture than did the metaphorical language of the Cistercians and of romance literature.

85. Bloch, Etymologies and Genealogies, I0I, I I6.

86. "Oculi venis intumescunt sanguineis, et versati terribilem praebent intuitum. Os distortum in partes spumas sanguine infectas evomit, cum membra quidem reliqua nulla quiete fruantur" (De rebus gestis in Majori monasterio, no. 5, p. 397, with corrections from Charleville II7, fol. II Iv).

87. De rebus gestis in Majori monasterio, nos. 8, II, pp. 398-99, $40 \mathrm{I}$.

88. On the genre and its realism, see Brémond, Schmitt, and Le Goff, "Exemplum," esp. $79-80$. 
In its approach to emotional bonds, as in its language, the Deeds of the Abbey of Marmoutier, like other literature from Marmoutier, differed from that of the newer religious orders. Like the members of the new orders, the monks of Marmoutier were interested in a spirituality that emphasized the "wondrous ardor of love." In their actual discussions of relationships, however, the monks of Marmoutier did not go beyond the insights of the earlier monastic tradition of friendship; they did not, like the Cistercian Aelred of Rievaulx, distinguish the special relationships among intimate friends from generalized Christian charity. 89

Nevertheless there were important similarities, both in content and in intent, between the treatment of relationships in Marmoutier's ghost stories and the one we find in the twelfth-century cult of friendship. In both cases we can detect attempts to reinforce the new community with personal bonds. Marmoutier's author, however, probably focused more narrowly on the community of Marmoutier and its empire than did many of the others. Aelred of Rievaulx's literature on friendship tended to address the monks in his own abbey, but Cistercians as well as others could take vows of friendship-which entailed obligations of prayer-with men they had never seen. The intimacy of daily contact was not present in these cases, but the intimacy of mutual intellectual and spiritual concerns, which could be shared through letters, took its place. 90 Unlike the author of the Deeds of the Abbey of Marmoutier, the most self-conscious men of the day explored a form of intimacy that took place on an intellectualized, nonsensory level. Indeed, it appears that in many cases they embraced and extolled the emotional possibilities of detached communities that were bound together by written documents. The primary concern of the author from Marmoutier, by contrast, was to ameliorate some of the problems the more abstract social bonds created. Marmoutier's author shared with the others, however, the sense that the monastic role of "bearing one another's burdens" was now a personal responsibility that each monk assumed for those with whom he as an individual had special ties and obligations. Peter Damian even wrote a ghost story that resembles those of Marmoutier, except that it was about two monks who were joined by a pact of friendship. That pact was so effective that when the more irreproachable of the two friends died he had to undergo punishment for the sins of the other. 91

89. McGuire, Friendship and Community; Fiske, Friends and Friendship in the Monastic Tradition.

90. Morris, Discovery of the Individual; Southern, Saint Anselm and His Biographer, 72-76.

91. Peter Damian, Epistolae, 8:20, PL I44:403-4. 
Still very much embedded in the old world, the ghost stories of Marmoutier point to the new, and they suggest just how profoundly the older life and traditions of the countryside, the nobility, and the Benedictines could be transformed by the logic and psychology of long-distance relationships and bureaucratic organization. By the twelfth century Marmoutier was far from being a local institution with purely local ties. Itself an empire, its well-being was tied in part to its relations with two other empires-Angevin and papal. Though a landed institution, it was nevertheless an active force in the new money economy, and the management of both its properties and its intercessory function required a sophisticated organization and division of labor. Its circle of associations was greatly extended, and its contacts, even those within the monastic community, were often rendered impersonal. In this kind of world, with these kinds of activities and relationships, not only urban dwellers, not only bankers and Scholastics, but also black monks were searching for new ways to affect individual behavior and to bind people together. The monks of Marmoutier saw one avenue of approach in the appeal to the conscience, motivation, and emotions of the individual. As part 3 of this book demonstrates, however, the appeal to the individual's conscience was not the only way of dealing with the problems of complex social organization and order.

Before we turn, in that section, to a discussion of the canons of Saint-Martin, we must look at another problem the monks of Marmoutier faced in the twelfth century-the problem of preserving their past. In an age of rapid change, the abbey's links to the time of Saint Martin seemed increasingly tenuous. Nevertheless, their collective identity rested upon their inheritance from that remote past. 